\title{
Checks and Balances? Leadership Configurations and Governance of NGOs in Chile
}

DOI:

10.1108/ER-08-2019-0327

\section{Document Version}

Accepted author manuscript

Link to publication record in Manchester Research Explorer

\section{Citation for published version (APA):}

Diaz, D., \& Rees, C. (2020). Checks and Balances? Leadership Configurations and Governance of NGOs in Chile. Employee Relations, 42(5), 1159-1177. https://doi.org/10.1108/ER-08-2019-0327

\section{Published in:}

Employee Relations

\section{Citing this paper}

Please note that where the full-text provided on Manchester Research Explorer is the Author Accepted Manuscript or Proof version this may differ from the final Published version. If citing, it is advised that you check and use the publisher's definitive version.

\section{General rights}

Copyright and moral rights for the publications made accessible in the Research Explorer are retained by the authors and/or other copyright owners and it is a condition of accessing publications that users recognise and abide by the legal requirements associated with these rights.

\section{Takedown policy}

If you believe that this document breaches copyright please refer to the University of Manchester's Takedown Procedures [http://man.ac.uk/04Y6Bo] or contact uml.scholarlycommunications@manchester.ac.uk providing relevant details, so we can investigate your claim.

\section{OPEN ACCESS}


This is pre-publication version of the manuscript which was accepted on 30/01/2020. It is yet to be edited and proofread by the journal.
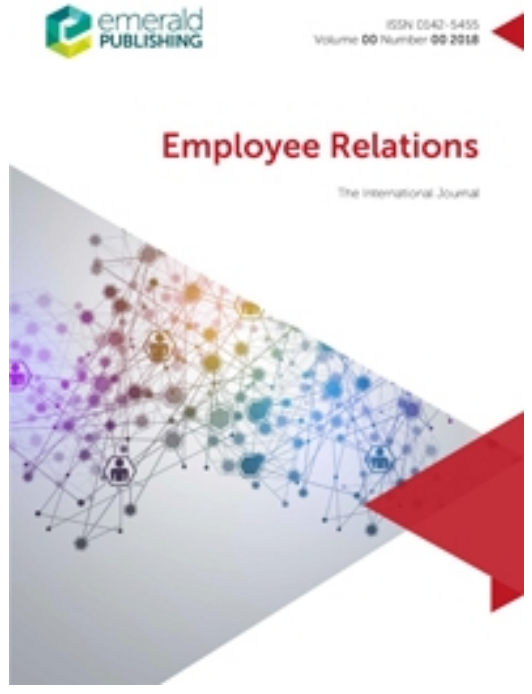

\section{Checks and Balances? Leadership Configurations and Governance Practices of NGOs in Chile}

\begin{tabular}{|r|l|}
\hline Journal: & Employee Relations \\
\hline Manuscript ID & ER-08-2019-0327.R1 \\
\hline Manuscript Type: & Research Paper \\
\hline Keywords: & Executive Director, NGO, Chile, Governance, Board of Directors \\
\hline \multicolumn{2}{|l}{} \\
\end{tabular}




\title{
Checks and Balances? Leadership Configurations and Governance Practices of NGOs in Chile
}

\author{
Daniel Diaz and Christopher J. Rees
}

\begin{abstract}
Purpose The emergence of governance practices in the non-governmental organisation (NGO) sector has become associated with increasingly high levels of organisational complexity. In the light of an expanding civil society sector in Chile and the emergence of formalised governance practices, this paper explores the construction of the Executive Director role in Chilean NGOs with reference to organisational functions, organisational dynamics including the distribution of power, and external influences.

Design/Methodology/Approach Grounded theory is used to explore qualitative data derived from a set of $\mathrm{N}=39$ interviews conducted in Chile These interviews involve NGO founders, funders, Executive Directors, scholars, consultants, and team members.

Findings The findings reveal the pivotal role played by Executive Directors in conducting organisational activities which, in other types of organisations, are often distributed across various organisational functions. The data also highlight complex dynamics involving overt compliance with external regulatory requirements, uncertainties about financial sustainability, the recruitment of Executive Board members, the exercise of power by Executive Directors, and the influence of founders in leadership configurations.

Research Limitations/Implications The implications of the study are discussed in relation to the nature of the Executive Director role, the governance and accountability of NGOs, the purpose of Executive Boards in the NGO sector, and the recruitment and training of Board members. It is noted that the study was conducted in the NGO sector in Chile; further research is necessary to establish the generalisability of the findings to other contexts.

Originality/value This paper contributes by offering analytical perspectives on organisational processes of leadership and governance. The paper highlights the relationship between, and interdependency of, those processes. It also contributes by addressing the shortage of organisational research on NGOs in Latin America and in Chile in particular.
\end{abstract}

Keywords: Executive Director, NGO, Chile, Governance, Boards of Directors

\section{INTRODUCTION}

Organisational dynamics relating to leadership play a central role in providing decisions and guidance through the definition and embodiment of purposes, the championing of institutional integrity and the ordering of internal operations (Weisbord, 1976). Reflecting on the challenges for Nongovernmental Organizations (NGOs), Ronalds (2010: 118) asserts that leaders and managers are "the single most critical element in these organisations effectively responding to the increasingly complex and unpredictable challenges they face". As NGOs have increased in number and grown in 
complexity, the leadership of these organisations has required plurality of perspectives and experiences in order to achieve emerging expectation of effectiveness, efficiency and accountability (Bies, 2010; Drucker, 2012; Maier et al., 2016; Sanzo-Pérez et al., 2017). This requirement for plurality has, in part, led to the creation of governance mechanisms intended to enhance the overall conduct, sustainability and accountability of the organisation from a strategic level of analysis (OECD, 2015a; Renz, 2016; Wyatt, 2004). In the past, leadership and its associated power could often be traced back to a single individual, such as a founding figure. In more recent times, however, the emergence of governance mechanisms has created the expectation of a distribution of that power which typically involves a Board of Directors or Trustees headed by an Executive Director (Clarke, 2004; Li, 2019).

This new scenario involving shared responsibility sets challenges Trustees, Board members or Directors; and those occupying the position of Executive Director. Notably, there has been research in the dynamics between those roles once they are already in their responsibilities (Cornforth, 2001; LeRoux and Langer, 2016; Renz, 2016; Salipante, 2014; Wyatt, 2004). However, there is a dearth of research which has explored the process of configuring that dyad; that is the construction of the role of Boards of Directors and the Executive Director as a parallel phenomenon specifically in the NGO sector.

In order to address this gap in knowledge, the paper presents the results of research about governance practices within Chilean NGOs with reference to the governancedriven construction of Boards of Directors including the Executive Director role. As such, the main aim of this paper is to explore how configurations of leadership are being developed in response to the formalisation of governance practices within NGOs in Chile.

The case of Chile has been selected as it offers an opportunity to focus upon a rapidly developing NGO sector which has largely emerged since 1990 in the post-dictatorship period (ChileTransparente, 2010a, 2010b, 2010c; Diaz de Valdés, 2017; Moya et al., 2012; Soto and Viveros, 2017). Further, despite the growth of the NGO sector since 1990, there is growing evidence (Aninat and Fuenzalida, 2017; Bethmann et al., 2019; ChileTransparente, 2010a; Diaz de Valdés, 2017) to indicate that NGOs in Chile are heeding generalised calls from different actors such as governments, corporate donors and philanthropic organisations to adopt professional governance practices (Blackwood et al., 2014; Edwards and Hulme, 1995; Eikenberry and Kluver, 2004; Eikenberry and 
Mirabella, 2018; Lee, 2016; Lewis, 2019). The adoption of these governance practices is taking place in a national context which has become associated with rampant neoliberalisation of the market and wider society (Clark, 2017; Duquette, 1998; Harvey, 2005),

\section{Background: the NGO sector in Chile}

There were reported to be 234,502 civil society organisations in Chile in 2016 (Centro UC Políticas Públicas, 2016a), which is $120 \%$ higher than the last comprehensive study from 2006 (Irarrazaval et al., 2006). A review published in 2017 indicates that almost $90 \%$ of these organisations were created after 1990. Of the total, 86,702 are focused exclusively on social and development services. The sector represents $2.1 \%$ of Chile's GDP and employs the equivalent of 310,119 full-time workers (Irarrazaval and Streeter, 2017). Further, in relation to social perception, there is evidence to indicate that social organisations that provide services to people in need are very well regarded in Chile (Centro UC Políticas Públicas, 2016b).

NGOs in Chile are regulated under a law passed in 2011 which established a regulatory body for civil society organisations (Government of Chile, 2011). Up to that point, statutory oversight had been scattered among a number of legal bodies. The 2011 legislation made explicit the norms and roles that regulate the activities of a wide range of organisations that fall under the broad category of civil society organisations. The legislation provided a comprehensive legal recognition of these kind of organisations involving their constitutional right to association, their opportunity to attain legal recognition, their right to perform economic activities and the availability of electoral tribunals (Soto and Viveros, 2017). Nevertheless, this 2011 Bill is vague in terms of governance and leadership. At a fundamental level, it requires civil society organisations to register in the corresponding municipality and to name a Directory with a minimum of three members, one of which is the Chair and legal representative of the organisation. It is also requires civil society organisations to submit an annual report to the Ministry of Justice. In the absence of highly prescriptive lists of duties and requirements, these organisations have a degree of discretion about they govern and regulate their activities.

The NGO sector in Chile has been the subject of research studies which have explored its size and scope (Irarrazaval et al., 2006; Irarrazaval and Streeter, 2017), its social role (Delamaza, 2010; Rodríguez, 1995), the quality of services provided, (Funk, 2015; Matus et al., 2012; Rios, 2006) and the philanthropic scenario (Aninat and Fuenzalida, 
2017). Thus, in general, research has been focused on the description of the sector from different perspectives. What has been less observed are the processes that underpin the proliferation and management of NGOs in Chile, especially the subject of organisational dynamics involving governance and leadership (Lewis, 2019).

In the following sections of the paper, the literature review that informed the study is presented. This review culminates in a set of four emergent research questions. The methodology that was designed to address these questions is then articulated. In the latter sections of the paper, the findings of the study are presented and discussed with reference to their implications for policy and practice.

\section{LITERATURE REVIEW}

\section{Definition of NGOs and organisational complexity}

In this research NGOs are defined using parameters devised by the United Nations (UN). In these parameters, the UN describe NGOs as: '(a) organizations; that (b) are not-for-profit and, by law or custom, do not distribute any surplus they may generate to those who own or control them; (c) are institutionally separate from government; (d) are self-governing; and (e) are non-compulsory' (United Nations Statistics Division, 2003, p. 17). This definition underscores key differences between NGOs, organisations in the for-profit sector and governments in relation to, for example, the clear institutional separation which should exist between governments and NGOs and the non-profit mission of NGOs. This non-profit characteristic highlights one of the main challenges surrounding the application of conventional approaches to management within NGOs:

"[N]on profits do not base their strategy on money, nor do they make it the center of their plans, as so many corporate executives do. 'The business I work with start their planning with financial returns', says one well-known CEO who sits on both business and non-profit boards, 'The non-profits start with the performance of their mission,", (Drucker, 1989, p. 89)

The non-profit mission which is highlighted by Drucker draws attention to complexities surrounding the practice of management within NGOs given that management represents 'the process of communicating, coordinating and accomplishing action in the 
pursuit of organizational objectives, while managing relationships with stakeholders, technologies and other artefacts, both within as well as between organizations' (Clegg et al., 2019, p. 4). For example, building on Handy (1988), people working in NGOs may have motivations linked to an elevated sense of altruism which originally led them to seek a paid or unpaid position within the NGO sector. As Lewis (2019) points out, managing a workforce in which paid staff are working alongside volunteers is particularly challenging for those involved with selection and performance assessment activities. Similarly, at the organisational level, Hudson (1999) highlights that there is often no direct link between the provider of resources and the users of services in the NGO sector thus further complicating management processes associated with the measurement of efficiency and accountability of NGOs.

\section{NGOs and governance practices}

Over recent years, stability in the NGO sector has become increasingly associated with routines and practices which are centred on governance issues (Deloffre, 2016). The functions of governance are closely associated with a Boards of Directors or Trustees. They are formal and sometimes statutory structures established with a group of people which varies in the number of its members and which exercise collective leadership over the entire organisation (Cornforth, 2001; Cornforth and Brown, 2013; Renz, 2016; Wyatt, 2004).

Governance represents the highest level of organisational steering and has been defined as:

“...the process of providing strategic leadership to the organization, a process that begins with making informed organizational choices: choices about why we're here, what we want to accomplish, how best to achieve those results, the resources we will need to do these things and how we will secure them, and how we will know whether we are making a difference." (Renz, 2016, p. 132).

The use of the inclusive word 'we' in Renz's definition highlights that governance practices are directly connected to the so-called 'agency problem' identified in wider business and management literature. For example, Zattoni and Cuomo (2008: 1) state: "The separation between ownership and control in large companies leads to the need for corporate governance" That is, the need for governance becomes particularly apparent when shareholders and founders are, for a variety of reasons, unable or unwilling to manage directly a given organisation in its entirety. In such circumstances, organizations bring in professional managers to perform managerial tasks. One of the 
major issues to arise is whether these managers make decisions in the best interests of the founders and shareholders or whether, in some cases, they may be following an alternative agenda for ulterior motives such as personal gain (Jensen and Meckling, 1976; Roberts, 2005). In this vein, Monks and Minow (2011, p. xxii) state that corporate governance is:

"... the structure that is intended to make sure that the right questions get asked, and that checks and balances are in place to make sure that the answer reflects what is best for the creation of long-term, sustainable, renewable value".

The prolific emergence of governance practices in the NGO sector (Bloodgood et al., 2014) has become associated with increasingly high levels of organisational complexity involving two key issues. First, at a practical level, the growth of the operations of NGOs has meant that, in some cases, founders of NGOs are no longer able to control directly operational processes (Moore and Stewart, 1998). Across different types of organisations and sectors governance mechanisms have been established as a means to represent the interests of key individuals and bodies by ensuring that the decisions of professional managers are appropriately aligned with the interests of these people and bodies (Coule, 2015; Morck and Steier, 2005). Second, at the societal level, the creation of governance mechanisms serves the purpose of allocating the responsibility of, and accountability for, organisational actions (Bovens et al., 2014; Crack, 2019). As Edward and Hulme (1995: 227-228) state so succinctly: "...the development of NGOs, their ability to attract support and legitimacy as actors in development, will depend largely on their ability to demonstrate that they can perform effectively and that they are responsible for their actions". Boards of Directors, hence, are expected to create and sustain organisational accountability, since "[NGOs] directly or indirectly benefit from the support of the public sector, they are expected to demonstrate a high degree of responsibility to the surrounding community" (Wyatt, 2004: 5b). In effect, the formal characterisation of governance highlights its checking and balancing function relating to the collective conduct of the agents of the organisation including Executive Directors.

There has been longstanding recognition that NGOs should be formally accountable to their Boards of Directors (Moore and Stewart, 1998). Yet, there are also complex dynamics of governance and accountability involving founders of NGOs, Boards of Directors, and other stakeholders. These dynamics lie at the heart of the mission, purpose and day to day activities of organisations within the NGO sector. Thus, while Boards of Directors represent a formal internal characterisation of governance, the 
accountability of the NGO extends to other external stakeholders albeit, at times, less formally. That is: "Nongovernmental organisations are accountable to their boards, but accountability to their contributors and beneficiaries is more tenuous" (Natsios, 1995: 409). These complex dynamics of governance arrangements involving Boards of Directors may, at times, be accentuated by the recruitment processes which NGOs follow when appointing members to these Boards. For the workforce as a whole, the Non-Profit Employment Trends Survey (Nonprofit HR Solutions, 2013: 21) reported that the hiring of qualified staff within limited budget constraints represented the greatest staffing challenge for non-profit organisations in the United States of America. The nature of this challenge for the recruitment of members of Boards of Directors is, however, a highly under-researched subject. Thus, while recommendations for good practice surrounding the recruitment of Board members for NGOs are in evidence (Hailey, 2000), there is a paucity of research which has sought to shed light on how, in practice, the members of Boards of Directors are selected and what criteria are used to identify appropriate individuals. For example, Ihm and Shumate (2019: 474) note that, in the non-profit sector, the "...board of directors, as individuals, may bring varied resources and take more active roles in facilitating and determining non-profit collaboration beyond turning their personal affiliations into organizational collaboration". What is unclear from literature, however, is the extent to which an individual's potential to present organisational collaboration opportunities to an NGO is considered to be a key factor when deciding whether to appoint such an individual to the Board of Directors of the NGO. Support for this observation is offered by research which has emphasised the importance of leadership succession in the NGO sector, as opposed to clarifying how leaders are appointed in this sector (Li 2019).

What is evident from existing studies, however, is that the installation of Boards in the NGO sector is linked to a broader process of professionalisation (Bies, 2010; Lewis, 2014, 2019) which emphasises the desirability of accountability, transparency and efficiency (Brown, 2005; Coule, 2013; Liket and Maas, 2015; Sanzo-Pérez et al., 2017; Valentinov, 2011). Yet, within the NGO sector, certain aspects of the drive for professionalisation have proved to be controversial. For example, there has been criticism involving neoliberalisation of the sector (Kamat, 2004; Klees, 1998), the implementation of market oriented tools (Maier et al., 2016), the extreme influence of capitalist philanthropy (Eikenberry and Kluver, 2004; Eikenberry and Mirabella, 2018) and concerns regarding EDs adopting entrepreneurial practices and rationales, more closely aligned to competitiveness than to social development (Sandberg, 2016). Hence, 
any analysis of these changes in governance practices ought to consider the broader scenario in which they are taking place.

\section{Leadership and the emergence of governance practices.}

The emphasis that the literature places on governance to achieve long-term sustainable value is relevant to this study since it highlights the possibility that governance practices may either intentionally or unintentionally, regulate, moderate or perhaps expand the power of founders who continue to occupy leadership roles. In effect, the introduction of formalised managerially-driven governance represents an organisational change which disrupts complex organisational dynamics by creating tensions within the configurations of leadership. These tensions have been addressed by Block and Rosenberg under the label of 'Founder's Syndrome' referring to "the influential powers and privileges that the founder exercises or that others attribute to the founder" (2002, p. 354). Moore and Stewart (1998: 337) articulate something of the nature of these tensions as follows:

"The founders of NGOs often do not want to adopt the more formal ('bureaucratic') structures that are implied by rapid growth in funding and in the diversity of donor sources... Founders may suspect that all this is an excuse to place power, authority, and perhaps even illicit resources, in the hands of the incoming professional managers, accountants, and impact evaluation specialists".

This observation underscores the interdependency of the diverse elements involved in governance and informs the necessity for a systemic perspective of analysis to consider their intertwined elements and dynamics. In essence, governance rests on organisational complexity that both requires and justifies its existence and operation. Much of that complexity derives from the operational characteristics and demands of the context in which organisations such as NGOs are operating (Cadbury, 1992; Carver, 2007; OECD, 2015b). For example, writers such as Matus et al. (2012), Salvato and Rerup (2011), Vromen (2011) have identified the role that is played by organisational routines in situations where there is goal conflict particularly involving people working at different levels of organisations (see Funk, 2015). Similarly, from an HRM perspective, Strobel et al. (2017) investigated the effect of individual variables such as personality and contextual antecedents such as work design on employees' proactive strategic behaviour; in their conclusions they highlight the importance of identifying contextual 
antecedents for the purpose of tailoring HR systems in areas such as recruitment and selection and training and development. This standpoint resonates with Brewster at al.'s (2015) views regarding the effects on HRM practices of institutional factors such as the extent of unionization and characteristics of the economy in which the organisation operates. Furthermore, organisational capacities, such as governance, have been linked with HR practices (Alaali and Rees, 2018), thus reinforcing the relevance of conducting research in a more integrated manner.Yet, despite widespread acknowledgement of the value of systemic perspectives, research which examines the contextual antecedents of governance and their subsequent impact on leadership configurations and HR practices specifically in the NGO sector is notable by its scarcity especially as it relates to developing countries. In addressing this gap, this study is focused on the NGO sector in Chile for reasons explained earlier.

\section{Summary and Emergent Research Questions}

The literature review reveals that governance practices are directly associated with leadership within the NGO sector though, with specific reference to the NGO sector, the review found scant empirical evidence to indicate that the process of formalisation and installation of governance has played a significant role in simplifying the complex leadership dynamics which involve stakeholders such as founders, professional managers, and external agencies. Rather, the findings of a number of studies suggest that governance-driven practices may, at times, further complicate issues surrounding agency and power within the sector. In reviewing related literature, it is notable that there is a dearth of research which has sought to isolate the contextual antecedents associated with the development of governance mechanisms, in the form of Boards of Directors, in the NGO sector or indeed the impact of these mechanisms once implemented. More specifically, while studies have drawn attention to the central function played by the Boards of Directors of NGOs, it remains unclear how the reconfiguration of power following the creation of a Board of Directors might occur, the nature of the leadership associated with the Executive Director role in the NGO sector, and the main purposes of Boards of Directors as perceived by key stakeholders.

Given the research gaps identified by the literature review, a set of four emergent research questions was constructed. These questions are presented below.

1. What contextual antecedents are informing the implementation of governance practices in the NGO sector in Chile?

2. What do NGO stakeholders in Chile regard to be the main purposes of Boards of 


\section{Directors?}

3. In the context of Chile, what is the nature of the leadership role which is being configured for NGO Executive Directors?

4. What criteria are used when recruiting members of Boards of Directors in Chile?

The methodology designed to address these questions is articulated below.

\section{Methodology}

The national context in which this study was undertaken is Chile. Grounded Theory was selected for this study in order to use an inductive process to define, in a generative manner, concepts that might underlie the phenomenon being observed. Thus, rather than approaching data with fixed theories, the researchers attempted to attain theoretical sensitivity by generating a sequential construction of the findings from the ground, in the form of outcomes that are not intended to fit into pre-existing theoretical frameworks (Glaser, 1978). Initial and focused coding was used to identify emerging categories which are represented in the findings of the study (Charmaz, 2006; Glaser and Strauss, 1967). This approach to grounded theory, which fits into the characteristics of the current inquiry, is intended to convene multiple 'voices' regarding a subject (Charmaz, 2006).

In devising a sampling strategy, the researchers sough to obtain different perspectives regarding governance in the NGO sector in Chile. 39 interviews were conducted, reaching theoretical saturation in the covered topics. The selection of these respondents was designed to represent different aspects of the practice of governance in the NGO sector in Chile. Nineteen respondents worked in NGOs; these respondents included four Board Members (NGBM); four Founders (NGOF); six Executive Directors (NGOED; and five Team members (NGOTM). These NGOs had been operating for at least ten years, with a governance body in operation for at least three years. Were considered NGOs in the Group 4 of Social Services, according to the International Classification of Non-Profit Organizations - ICNPO (United Nations Statistics Division 2003). Participant NGOs conduct their activities combining advocacy and providing services in poverty alleviation, local development, children protection, jail inmates social integration, reconstruction after natural disasters, youth and sport promotion.

In order to cover complementary perspectives from organisations that works with and in NGOs, also were considered were considered six respondents from umbrella NGOs 
$\left(\mathrm{UNGO}^{1}\right)$; the purpose of these organisations includes supporting the work of NGOs through financing or technical assistance, fitting into the Group 8 of Philanthropic intermediaries and voluntarism promotion (United Nations Statistics Division 2003). Eight respondents worked for consultancy firms (CONS) which specialise in philanthropy, third sector or corporate governance, and which all had NGOs among their clients. Six respondents were academics (SCHO) whose research is on aspects of management and/or governance on NGOs, third sector, philanthropy or civil society organisations.

The semi-structured interviews were conducted using a script based on the research questions and were carried out between October 2018 and February 2019. For example, the interviewees were asked about when and why governance practices were first introduced in the organisations; criteria in selecting board members; or the perceived results and outcome of having a Board on charge of the governance. The language of interaction was Spanish and two-way translation validation procedures were used to confirm the overall quality of the English to Spanish and Spanish to English translations of the interview questions and the interview data. The interviews were recorded with participants' consent. Ethical approval for the study was sought from, and granted by, an established University in the U.K. with which the researchers are associated.

\section{Findings}

The structure of this section of the paper is based on the research questions. Hence, it begins by reporting findings relating to the contextual antecedents which are informing the implementation of governance practices in the NGO sector and then proceeds to report findings relating to the remaining three research questions.

\section{The contextual antecedents informing governance practices}

When questioned about contextual antecedents which inform the implementation of the governance practices, the respondents identified various factors. The majority of respondents initially referred to legal considerations which, they argued, directly relate to governance issues within the NGO sector in Chile. Specifically, the majority of the respondents referred to a bill introduced in Chile in 2011 which makes explicit the norms and roles that regulate the activities of a wide range of organisations that fall under the broad umbrella of 'civil society' organisations. One of the emergent themes

\footnotetext{
${ }^{1}$ These codes are used later in this article to identify the sources of the quotes reported in the Results section.
} 
derived from the interview data was the extent to which the respondents perceived that vagueness in the wording of this legislation had created ambiguities within the NGO sector. For example, two of the respondents stated the following:

"The law requires you ... to have a Board of Directors when you establish your institution... My question is: are positions on the Board well filled? ... Then the answer is complicated, because, and from a transparency point of view, the answer is 'yes, they are covered', but nobody guarantees you that they are really covered well. So, Boards of Directors exist but they don't necessarily work well" (CONS_08).

"From Law 20,500 it is assumed that the Civil Registry keeps track of all civil society organizations ... But the registration system does not work very well, it has had several problems fundamentally as regards data migration from the Municipality to the Civil Registry ... Then, when we are talking about public faith ..., there is still a very precarious situation" (SCHO_03).

In addition to contextual considerations involving legal issues, the majority of the respondents drew attention to a growing societal interest in the governance of NGOs in Chile. The interview data indicate that the respondents attributed this interest to general erosion of public trust toward public institutions. Indicatively, two of the respondents stated the following:

"In Chile, there is a great crisis of trust in all institutions with no escape... the Catholic Church, the government, the armed forces ... Society places a high value on civil society organisations ... we must take care of it ... I would say that there is not much accountability... I tell you that it is a topic that is beginning to receive attention" (SCHO_03).

"It is seen that outside there is a spirit of change and, although it is small, there are some donors who do try to donate not only by knowing a person, but because they believe they are going to do the job better"(NGOF_01). 
Interestingly, respondents highlighted that Umbrella NGOs and Consultancy firms in Chile have actively promoted good governance as an important practice within a national context in which there is a lack of public trust in institutions. Several of the respondents expressed the view that this lack of public trust was highlighting weaknesses in NGO governance and was, in effect, a call for action in this area of operation. For example, one respondent stated the following:

"Look, the truth is that the current state [of NGO governance] is quite weak. I think that [this sector] has to be professionalised in every way..., Boards of Directors or committees, all the governance of the organisations has to improve" (CONS_05).

Another contextual consideration raised by the respondents was the influence of private sector organisations which were considered by many of the respondents as the benchmark for modern and efficient management practices, including governance. For example, three of the respondents stated the following:

"Civil society must be as efficient as the private sector... We can do charity, we can be philanthropists, but that does not detract from efficiency..." (UNGO_03).

We see that there are corporate tools that are necessary to make the best management in the philanthropic world. For example, the selection of personnel. Competitive salaries. Bringing in the best talent. Improving people's productivity. Measuring and evaluating performance... With the values of a company, but with the logic and purpose of a foundation, they have also allowed us to make people happy. (UNGO_01)

We have management control systems that set management goals. And from those management goals, the department goals are derived and the individual goals...; people are evaluated, just like in a company. (UNGO_01)

\section{Respondents' Perceptions of the Main Purposes of Boards of Directors}


The respondents were asked to provide their views about the main purposes of Boards of Directors in the NGO sector in Chile. In response to this line of questioning the vast majority of the respondents referred to the issue of financial sustainability. The emphasis on this issue was indicatively summarised by several respondents as follows:

"But deep down, the [theme of the] Board, strongly, strongly, is where we get money from ... I tell you that $80 \%$ [of the conversation is] money and $20 \%$ the other (....) that is, money, money, money, money, money all the time ... Where do we get money?" (NGOBM_03).

"The number one need is for financing... Indeed, when the time for funding comes, I think it is when the need to formalise arises the most" (CONS_06).

"On the Board that I was on, were six people; the only thing that interested them was how we could have more press, more television, so that I would get more press releases and money. It was just money. One had been a manager of a transnational dairy company, another that came from retail, and another managed the family office of a Chilean billionaire" (NGOED_05).

This perceived emphasis on financial considerations existed across the entire group of respondents. For example, one Team leader expressed the view that:

"The Board is the one that manages money. This is a committee that has to do with the money. They organise where to get more money. They evaluate the achievements of the work from time to time. I think that is what they do" (NGOTM_04).

It was recognised, however, that the overriding focus on financial considerations did, at times, detract from other key purposes of NGOs. For example, one respondent expressed this viewpoint as follows:

"To be sustainable over time, NGOs begin to participate in areas of action ... which are not necessarily part of their core... but this raises the money that allows me to finance something that I really want. But 
in the end, it turns out that it takes away $70 \%$ or $80 \%$ of your time... to thereby finance $20 \%$ of the core. (SCHO_06)

\begin{abstract}
Notably, a distinct group of the respondents emphasised that the urgency for the Board of Directors to raise money impacted upon a wide range of both internally and externally focused activities; thus even communication materials designed to explain the work of the NGO had become imbued with requests for money. One respondent cited an example of promotional material in which fundraising was the pre-eminent theme:

"... as I said the first priority is to raise money (...). So there is the video, the campaign. For example, on [the website of a foundation] the first thing that comes out is the video of people talking ('I dreamed and imagined how I was going to be at 80 years old') to touch the [emotional] fibres; that's the first thing - they try to touch you, the donor's sensitivity... That is the first focus, because it is the first need. (NGOF_01).
\end{abstract}

\title{
Recruitment of Members to the Board of Directors
}

The findings of the literature review revealed the dearth of empirical studies which have examined how and why individuals are recruited to Boards of Directors in the NGO sector. As an element of this study, the respondents were asked a series of questions about their perceptions of the recruitment of Board members. The main theme to emerge from this line of questioning was the issue of trust. That is, Boards do not represent a threat to key stakeholders if close and trusted collaborators are recruited as members. One respondent summarised this perspective as follows:

"We always build the Board with trusted people, not with great authorities... My dad, for example, must be somewhere as one of the different legal personalities; we have, a friend from school; another university professor... [another founder's] father is the president of the foundation ... And in general, it has worked" (NGOF_04).

Corollaries of this approach to recruitment were identified by a sub-group of the respondents during follow-up questions. For example, the interview data reveal an existent perception among the respondents that recruitment of Board members within 
the social circles of the founder and other Board members has led to a lack of diversity at Board level in relation to factors such as gender, social background, and ethnic origin. Further, this lack of diversity has led to limited awareness among Board members about some of the social issues which NGOs are supposed to be addressing. For example, two respondents stated:
“... many Boards are decoupled from social intervention.... The decoupling is because they do not really know what the programmes are doing and what the organization is doing for the user and to meet its objectives. [In addition] many of the Board members do not come from the world of social intervention... Therefore they do not know how things are done. (SCHO_O1)
"... the level of alignment of the Board of Directors with [the founder] was total. There was no questioning, deliberation. It is reverential, rigid and uniform" (NGOED_06)

During this phase of the interviews, the critical issue of finance was once again raised by a group of respondents who indicated that the recruitment of Board members is, on occasions, seen as an opportunity to secure funds to sustain the operation of the NGO. That is, funds could potentially be raised by recruiting people to the Board who were in a position to elevate the organisation's social appeal or to directly donate resources to the organisation. Indicatively, one respondent stated:
"The logic of the Board is that they have a management team overwhelmed by the lack of resources.... So the logic of the Board is to find someone who gives you a complementary look ... whether personally or through networks, [that person] can bring resources" (SCHO_05).

The interview data indicate that the respondents did not cite specific technical skills when asked about the criteria used to recruit Board members. A group of respondents did highlight, however, that knowledge of business and 'business logic' was actively considered during recruitment activities. Indicatively, this approach was summarised as follows by one of the respondents:

\footnotetext{
"We formed a Board of rock stars... A commercial manager of a multinational shoe company; an entrepreneur who owns a chain of
} 


\begin{abstract}
hairdressing salons with branches in Peru and Colombia and apart from that has an advertising agency; one of the owners of a big cured products company... They had the knowledge of how to do business management for social issues" (NGOF_03).
\end{abstract}

\title{
Configurations of Leadership with Reference to the Role of Executive Directors
}

The literature review established the existent lack of clarity surrounding both the reconfiguration of power following the creation of a Board of Directors and also with the nature of the leadership associated with the Executive Director role. During the interviews, these topics were explored and three main themes emerged.

First, respondents expressed the view that although Boards of Directors hold direct responsibility for issues of governance in the NGO sector, the relatively powerful role of the Executive Director is multi-faceted and ambiguous. Thus, when initially asked to articulate their perceptions of the role of an Executive Directors, some of the respondents described a wide range of tasks such collecting money during fundraising events, donating money to the $\mathrm{NGO}$, acting as a socially appealing figure in social settings, marketing, and solving organisational and legal issues. Some of the respondents, however, explicitly recognised the role ambiguity of the Executive Directors and expressed their own uncertainty about the work undertaken by those who occupy this position. For example, two of the respondents stated the following:

"I think there has been a problem in which it is not clear... What is the work of ... the Executive Director? If you don't know what you have to do, you're not going to do it, or you're going to do it wrong", (SCHO_06).

Because historically this was never done or practically never transparent, it was never established as a way of operating within organisations... A person comes voluntarily to hand over his time [as Director] and his energy inhibits him from being able to demand certain things for himself" (CONS_04).

Despite this ambiguity surrounding the role of Executive Director, the interview data reveal that respondents perceived the leadership role of Executive Directors to be both influential and empowered though, notably, the extent of this influence and 
empowerment was seen, by some respondents, to be linked directly to the occupant of the role. Indicatively, one respondent stated the following:

“... an Executive Director also arrives with a strong personality who is able to say no to the Board of Directors... or simply goes ahead without consulting, informing ... and things get done” (NGOBM_04).

As revealed by the quote above, the perceived empowerment of the leadership role of the Executive Director was attributed by some of the respondents to a lack of engagement in decision-making processes by members of the Boards of Directors. For example, four of the respondents stated the following:

"The Board of Directors is ... the Board of Directors. I personally do not know them. I had a joint meeting, and only three people came from the Board... I know them from hearsay and what they say, but not personally" (NGOTM_03).

"The level of involvement I had [as a Board member] was super circumstantial and occasional [in] the Board meetings... I participated in them and, at times, we had discussions, but there was an inertia that took us" (NGOED_01).

"I feel that there is a good atmosphere in them, but perhaps they are still at a stage ... of waiting for what I [as Executive Director] ask them to do to collaborate... They take the position of: 'if there is no news it is because everything will be fine' (NGOED_02).

"Executive Directors complain about their Board members: 'I stop for a week to prepare for a Board Meeting with some gentlemen who come to have a coffee, because they are interested in putting on their c.v. that they are a Board member'," (CONS_07).

When discussing the role of the Executive Director within leadership configurations, a group of the respondents specifically drew attention to the pervading influence of founders who may, or may not be, occupying the role of the Executive Director. For example, one of the respondents stated the following: 
"NGOs usually have a Board of Directors that is not a controlling Board... The problem ... is that the founder, who is usually a member of Board or the Executive Director ... facilitates contacts, networks, wisdom, and deals with crises. That is his role" (UNGO_02).

One group of respondents cited specific examples of how founders were exerting high levels of influence in leadership configurations albeit while not necessarily occupying Executive Director roles. For example, one of the respondents stated the following:

\begin{abstract}
"I [as Executive Director] suggested that I would need to change the statutes for different reasons ... and she [the Founder] welcomed and promoted it and finally the Board validated it... I also suggested that it was necessary to change the Board and also I argued that it was necessary for her to stop being president (NGOED_01).
\end{abstract}

"[The founder] was the natural leader of the foundation and the face of the foundation ... When we created the foundation in legal terms, he was already thinking about it and spoke with four close friends about becoming members of the board ... The Board of Directors was mostly a decorative structure that helped in certain things (NGOBM_04)

In an example drawn from a different NGO, one of respondents, a founder, articulated a scenario in which he decided that the Executive Director's position should be rotated among the founders who would constitute the Board of Directors. The respondent provided the following rationale for this decision:

We are going to make the best decisions and we can comment on them, but without pressure because we are involved here, because we are doing what we like... There is an internal knowledge among founders that allows us not to have an external Board.... If we had an external Board of Directors maybe they would say: 'look at the institutional risk of losing', 'what are the chances that it will work?'” (NGOF_04).

Thus, when considering role of the Executive Directors in leadership configurations, the interview data highlight that the Executive Director's relationship with founders of the $\mathrm{NGO}$, and the wider influence of these founders, is generally perceived by the respondents to be a critical consideration. 


\section{Discussion of Findings}

By addressing a set of four related research questions, the study examines configurations of leadership scenarios associated with the introduction of governance practices within NGOs in Chile. The research questions are focused on contextual antecedents which inform governance practices, stakeholders' perceptions of the main purposes of Boards of Directors, the criteria used to recruit individuals to these Boards, and the nature of the Executive Director role in this sector.

\section{Contextual antecedents}

As noted in the literature review, Strobel et al. (2017) have previously emphasised the importance of identifying contextual antecedents in order to enrich understanding of the interconnectedness between these antecedents and HR practices in areas such recruitment and selection and training and development. One of the main findings to emerge from the study is the extent to which the respondents linked the introduction of governance practices to relatively short-term organisational-level concerns with financial sustainability which are prevalent in the NGO sector. This financially-oriented perception confers an instrumental character to governance and appears to pervade activities surrounding governance in this context. Hence, while the respondents highlighted other contextual antecedents such as statutory obligations, societal interest in the governance of NGOs and the influence of private sector organisations, the issue of financial sustainability emerged as the key contextual antecedent which the respondents perceived to be informing governance practices at the organisational level. This also relates to a legal body that is perceived as vague. It is emphasised that the identification of these contextual antecedents emerged from a grounded theory approach to data analysis which enabled 'multiple voices' to resonate from the data as opposed to analysing data with reference to pre-existing theoretical frameworks. By offering qualitatively driven insights into stakeholders' perceptions of the contextual antecedents of governance activity in the NGO sector, these findings provide a complementary contribution to the emerging body of work in HRM literature which has sought to examine the influence on employees' behaviour and activities of contextual antecedents factors such as work design, unionisation, and the influence of the sector (Brewster et al., 2015). The main conclusion drawn from this finding is that governance practices and financial sustainability are seen by stakeholders as interconnected issues and this relationship should be recognised by policymakers who are seeking to monitor 
governance-related activities and to promote good governance and HR practices within the sector.

\section{Perceptions of the purposes of Boards of Directors}

The finding relating to governance and financial sustainability also sheds new light on stakeholders' perceptions of the main purposes of the Boards of Directors and the criteria used to recruit members to these Boards. For example, the findings reveal stakeholders' perceptions that Boards of Directors are formed because they are a legal requirement for NGOs but that the main purpose of these Boards is financial rather than governance-related. Thus, the findings highlight the perception that NGOs establish Boards of Directors, not to distribute power away from an influential individual such as a founder but rather to comply overtly with legislation. In effect, having been required to establish Boards of Directors, Board members are then hand-picked to address financial concerns and to create as little organisational upheaval as possible. Notably, when considering the criteria used for recruitment of Board members, the findings contain sparse evidence that an emphasis is placed on their leadership and technical skills aside from a general background in business. Rather, the findings of the study indicate that members of Boards are selected for their closeness to founders or Executive Directors and their ability to raise finance. Arguably, this approach to recruitment, diminishes the expectation of changes to balances of power resulting from the creation of a meaningful leadership role for the Board of Directors. There are two clear practical implications of this finding, both of which relate to the reported levels of "under-investment in effective hiring, retention and staff development practices" in the non-profit sector (Nonprofit HR Solutions, 2013). First, there is the need for more transparency and arguably independent auditing of recruitment processes surrounding the appointment of members of Boards of Directors. Second, the links between capacity building and human resource development have been recognized in wider literature (Alaali and Rees, 2018); given the ambiguities surrounding the purposes of Boards of Directors, it is vital that Board members receive formal training and development to develop their role-related awareness and skills.

\section{The role configuration of Executive Directors}

The findings of the study highlight that governance mechanisms in this sector appear to be a pragmatic reaction to statutory requirements. As a result, Executive Directors retain wide-ranging and central responsibility in the arena of organisational sustainability. 
Simultaneously, Boards of Directors are viewed by stakeholders as playing an instrumental role in decision-making processes partly as a result of their lack of diversity. Based on the findings of the study, the conclusion that we draw is that the introduction of the Board of Directors should not automatically be viewed as a capacity building initiative as these Boards may not actually exercise or indeed even hold meaningful positional power in decision-making processes. Paradoxically, the internal legitimacy and influence of individuals who occupy the role of Executive Directors may be heightened by the creation of a Board of Directors since the decisions taken by Executive Directors now appear to be backed by a formally constituted, but not necessarily independent, governance body. As a result, issues that should be addressed by Boards of Directors are retained within the decision-making domain of Executive Directors thus reinforcing individualized leadership configurations. In line with the observations of Moore and Stewart (1998) and Lewis (2019), the findings indicate the existence of resistance to formal and independent structures of governance and organisational routines within the sector, with the retention of power by Executive Directors appearing to one plausible causal explanation for this situation. This situation raises concerns regarding the efficacy of introducing governance practices, That is, the findings of this research reveal stakeholders' perceptions that, rather than exercising a degree of independence, governance bodies tend to reinforce the positions of EDs in a functional as opposed to strategic manner and thus serve to provide further legitimacy to decision-making which is carried out primarily by EDs.

While these findings relate directly to the so-called Funder Syndrome (Block and Rosenberg, 2002) highlighted earlier in the paper, this research also identifies the importance of other influences on leadership configurations in this context. One of the key influences identified is the extreme drive to achieve sustainability in a scenario involving influential philanthropic institutions and competition for funds. The findings indicate that this drive for sustainability, while understandable from the perspectives of stakeholders such as EDs, Board members and employees, permeates both the configuration and operation of governance bodies in such a way that expectations of checks and balances initiated for governance purposes may be neutralized from their inception.

The findings also represent a call for further research into the role and characteristics of EDs in the NGO sector in Chile. This research has revealed a scenario where legal regulations impose few boundaries, thus enabling more organic leadership configurations and processes to exist and thrive. In this scenario, hints of Founder 
Syndrome, when combined with a market driven environment, an overtly professionalized organizational context, and philanthropic pressures, creates a context in which entrepreneurial leadership styles can be practiced openly. In reinforcing concerns raised by Sandberg (2016), the findings reveal that the NGO sector in Chile is something of a melting pot in which neoliberal policies implemented in the postdictatorial period are enabling an entrepreneurial spirit of innovation characterized by an emphasis on sustainability and efficiency. In essence, NGOs have long been associated with activities such as upholding societal values such as democracy, pluralism, and empowerment, and advocating for local communities in areas such as health and education. It may be the case that when NGOs in Chile implement the governance structures and leadership configurations explored in this research, they improve their financial sustainability and increase their legitimacy in the eyes of institutional stakeholders such as corporate donors and philanthropic actors. What also remains unanswered is whether those improvements are outweighed by the costs to the NGO sector and their potential beneficiaries in the wider community.

\section{Conclusion}

This study reveals that governance mechanisms and leadership dynamics in the NGO sector in Chile require further research and development if effective changes to accountability, power distribution and decision-making processes are to be achieved. From a systemic view of organisations, leadership in complex organisations, such as NGOs, requires a collective configuration in which power has been distributed. The findings of this study suggest that, in the case of NGOs in Chile, the introduction of Boards of Directors as a governance mechanism has not necessarily led to collective configurations of leadership. That is, despite the introduction of Boards of Directors, key stakeholders perceive that Executive Directors and founders of NGOs are retaining high levels of control over resource allocation and wider decision-making processes. These findings have implications which relate to the stated and perceived purposes of Boards of Directors, the processes surrounding the recruitment and training of members of these Boards, and the role of Executive Directors within the NGO sector.

Finally, we highlight that this research has involved respondents drawn from a set of organisations in Chile. There is a need for further research to establish the generalisability of the findings to NGOs operating in other national contexts

\section{Bibliography}


Alaali, L. and Rees, C.J. (2018), "Sustainability, Performance and Development: Towards an Understanding of the Intersections between Human Resource Development (HRD) and Capacity Building", International Journal of HRD Practice, Policy and Research, Vol. 23 No. 2, pp. 23-34.

Aninat, M. and Fuenzalida, I. (2017), "Institutional Philanthropy in Chile”, Center for Philanthropy and Social Investments, School of Government, Universidad Adolfo Ibáñez, Santiago of Chile.

BBC. (2018), "Oxfam Haiti allegations: How the scandal unfolded", BBC News, available at: https://www.bbc.com/news/uk-43112200.

Bethmann, S., Meneses, C. and Aninat, M. (2019), Guía Para La Gobernanza Efectiva de Fundaciones y Corporaciones En Chile, CEFIS Universidad Adolfo Ibañez, Santiago of Chile.

Bies, A. (2010), Evolution of Nonprofit Self-Regulation in Europe, Nonprofit and Voluntary Sector Quarterly, Vol. 39, available at:https://doi.org/10.1177/0899764010371852.

Blackwood, A., Dietz, N. and Pollak, T. (2014), The State of Nonprofit Governance, Washington, DC, available at:

https://www.urban.org/sites/default/files/publication/22951/413229-the-state-ofnonprofit-governance.pdf (accessed 21 November 2017).

Block, S.R. and Rosenberg, S. (2002), “Toward an Understanding of Founder's Syndrome: An Assessment of Power and Privilege Among Founders of Nonprofit Organizations", Nonprofit Management and Leadership, Vol. 12 No. 4, pp. 353368.

Bloodgood, E.A., Tremblay-Boire, J. and Prakash, A. (2014), "National Styles of NGO Regulation”, Nonprofit and Voluntary Sector Quarterly, Vol. 43 No. 4, pp. 716736.

Bovens, M., Schillemans, T. and Goodin, R. (2014), "Public Accountability", in Bovens, M., Goodin, R. and Schillemans, T. (Eds.), The Oxford Handbook of Public Accountability, Oxford University Press, Oxford, pp. 1-20.

Brewster, C., Brookes, M. and Gollan, P.J. (2015), “The Institutional Antecedents of the Assignment of HRM Responsibilities to Line Managers", Human Resource Management, Vol. 54 No. 4, pp. 577-597.

Brown, W.A. (2005), "Exploring the association between board and organizational performance in nonprofit organizations", Nonprofit Management and Leadership, 
Vol. 15 No. 3, pp. 317-339.

Cadbury, A. (1992), The Financial Aspects of Corporate Governance, Gee, London, available at: http://www.ecgi.org/codes/documents/cadbury.pdf (accessed 22 November 2017).

Carver, J. (2007), "The Promise of Governance Theory: beyond codes and best practices", Corporate Governance: An International Review, Vol. 15 No. 6, pp. 1030-1037.

Centro UC Políticas Públicas. (2016a), Civil Society Organisations Map 2015 [Mapa de Las Organizaciones de La Sociedad Civil 2015], Santiago of Chile, available at: http://politicaspublicas.uc.cl/wp-content/uploads/2016/01/PDF-Brochure-Mapa-delas-Organizaciones.pdf.

Centro UC Políticas Públicas. (2016b), Social Value Index Chile 2016 [Índice de Valoración Social En Chile 2016], Santiago of Chile, available at: http://politicaspublicas.uc.cl/wp-content/uploads/2016/05/PDF-completo-segundoinforme.pdf.

Charmaz, K. (2006), Constructing Grounded Theory: A Practical Guide through Qualitative Analysis, Sage Publications, London.

ChileTransparente. (2010a), Guía Para Directores de Organizaciones Sin Fines de Lucro [Guide for Nonprofit Directors], Santiago of Chile, available at:

http://www.avina.net/avina//wp-

content/uploads/2013/06/Guia_para_Directores_de_Organizaciones_sin_fnes_de_1 ucro.pdf (accessed 24 October 2017).

ChileTransparente. (2010b), Herramientas de Incentivo Para Mejorar Los Directorios de Las Organizaciones Sin Fines de Lucro En Chile: Propuestas Para La Discusión [Incentive Tools to Improve Boards of Nonprofit Organizations in Chile: Proposals for Discussion], Santiago, available at: www.chiletransparente.cl (accessed 29 November 2017).

ChileTransparente. (2010c), Gobiernos Corporativos En Las Organizaciones Sin Fines de Lucro En Chile: Situacion Actual y Perspectivas [Corporate Governance on NPO in Chile: State of the Art and Perspectives], Santiago, Chile, available at: http://www.chiletransparente.cl/wpcontent/files_mf/13529894981347631066OSFLenChileDiagnosticoactual.pdf (accessed 19 October 2017).

Clark, T.D. (2017), “Rethinking Chile's 'Chicago Boys': neoliberal technocrats or revolutionary vanguard?", Third World Quarterly, Vol. 38 No. 6, pp. 1350-1365. 
Clarke, T. (2004), “Theories of Governance - Reconceptualizing Corporate Governance Theory After the Enron Experience", in Clarke, T. (Ed.), Theories of Corporate Governance: The Philosofical Foundations of Corporate Governance, Routledge, Oxon, pp. 1-30.

Clegg, S., Kornberger, M., Pitsis, T. and Mount, M. (2019), Managing and Organizations: An Introduction to Theory and Practice, 5th ed., Sage Publications, London.

Cornforth, C. (2001), "What Makes Boards Effective? An examination of the relationships between board inputs, structures, processes and effectiveness in nonprofit organisations", Corporate Governance, Vol. 9 No. 3, pp. 217-227.

Cornforth, C. (2003), The Governance of Public and Non-Profit Organisations: What Do Boards Do?, Routledge, Oxon.

Cornforth, C. (2012), "Nonprofit Governance Research: Limitations of the Focus on Boards and Suggestions for New Directions", Nonprofit and Voluntary Sector Quarterly, Vol. 41 No. 6, pp. 1116-1135.

Cornforth, C. and Brown, W.A. (2013), Nonprofit Governance : Innovative Perspectives and Approaches, Routledge, Abingdon.

Coule, T.M. (2013), “Governance in non-profit organizations: Accountability for compliance or legitimacy?", British Academy of Management BAM2013.

Coule, T.M. (2015), "Nonprofit Governance and Accountability: Broadening the Theoretical Perspective", Nonprofit and Voluntary Sector Quarterly, Vol. 44 No. 1, pp. 75-97.

Crack, A. (2019), "NGO Accountability”, in Davies, T. (Ed.), Routledge Handbook of NGOs and International Relations, 1st ed., Routledge, pp. 621-634.

Delamaza, G. (2010), “ONG, Sociedad Civil y Democracia en Chile Post Autoritario", in Sorj, B. (Ed.), Usos, Abusos y Desafíos de La Sociedad Civil En América Latina, Siglo XXI, Buenos Aires, pp. 61-118.

Deloffre, M. (2016), “Global accountability communities: NGO self-regulation in the humanitarian sector", Review of International Studies, Vol. 42 No. 4, pp. 724-747. Diaz de Valdés, L.M. (2017), “Trayectorias en cambio: Un recorrido por la historia de las organizaciones de la sociedad civil [Trajectories in change: The history of Civil Society's Organisation]", in Irarrazaval, I. and Streeter, P. (Eds.), Sociedad En Acción: Construyendo Chile Desde Las Organizaciones de La Sociedad Civil, Centro UC Políticas Públicas \& Chile + Hoy, Santiago of Chile, pp. 74-93. Drucker, P. (1989), “What Business Can Learn from Nonprofits HBR”, Harvard 
Business Review, No. July-August 1989, pp. 88-93.

Drucker, P. (1992), Managing the Non-Profit Organization: Practices and Principles, Butterworth-Heinemann, Oxford.

Drucker, P. (2012), “The Dimensions of Management”, Management: Tasks, Responsabilities, Practices, Taylor and Francis, St. Louis, pp. 36-46.

Duquette, M. (1998), “The Chilean Economic Miracle Revisited”, Journal of SocioEconomics, Vol. 27 No. 3, pp. 299-321.

Edwards, M. and Hulme, D. (1995), Beyond the Magic Bullet : NGO Performance and Accountability in the Post-Cold War World, Kumarian Press, New York.

Eikenberry, A.M. and Kluver, J.D. (2004), "The Marketization of the Nonprofit Sector: Civil Society at Risk?”, Public Administration Review, Vol. 64 No. 2, pp. 132140.

Eikenberry, A.M. and Mirabella, R.M. (2018), "Extreme Philanthropy:

Philanthrocapitalism, Effective Altruism, and the Discourse of Neoliberalism”, PS:

Political Science \& Politics, Cambridge University Press, Vol. 51 No. 01, pp. 4347.

Funk, R. (2015), Caracterización de Los Prototipos de Herramientas de Gestión Para Organizaciones Solidarias, Centro de Estudios de Emprendimientos Solidarios, Pontificia Universidad Católica de Chile, Santiago of Chile.

Glaser, B. (1978), Theoretical Sensitivity, The Sociology Press, San Francisco, CA.

Glaser, B. and Strauss, A. (1967), The Discovery of Grounded Theory: Strategies for Qualitative Research, AldineTransaction, New Brunswick.

Government of Chile. (2011), Ley $N^{o}$ 20.500. Sobre Asociaciones y Participacion Ciudadana En La Gestion Publica, Santiago of Chile, available at:

http://participacionciudadana.subdere.gov.cl/sites/default/files/Ley 20500 Sobre Asociaciones y Participacion Ciudadana en la Gestion Publica.pdf (accessed 10 November 2017).

Hailey, J. (2000), "NGO partners: the characteristics of effective development partnerships", in Osborne, S. (Ed.), Public-Private Partnerships. Theory and Practice in International Perspective, 1st ed., Routledge, London, pp. 329-341. Handy, C. (1988), Managing Voluntary Organizations, Penguin, Harmondsworth. Harvey, D. (2005), A Brief History of Neoliberalism, Oxford University Press, Oxford. Hudson, M. (1999), Managing Without Profit: The Art of Managing Non-Profit Organizations., Penguin, Harmondsworth.

Ihm, J. and Shumate, M. (2019), "How Does a board of Directors Influence Within- and 
Cross-sector Nonprofit Collaboration?" Nonprofit Management and Leadership. Vol. 29, No. 4, pp. 473-490.

Irarrazaval, I., Hairel, E., Sokolowski, W. and Salamon, L. (2006), Estudio

Comparativo Del Sector Sin Fines de Lucro - Chile, John Hopkins University, PNUD and FOCUS, Santiago de Chile.

Irarrazaval, I. and Streeter, P. (2017), Sociedad En Accion: Construyendo Chile Desde Las Organizaciones de La Sociedad Civil, Centro UC de Politicas Publicas, Santiago de Chile.

Jensen, M.C. and Meckling, W.H. (1976), "Theory of the Firm: Managerial Behavior, Agency Costs and Ownership Structure”, Journal of Financial Economics, NorthHolland Publishing Company, Vol. 3, pp. 305-360.

Kamat, S. (2004), "The Privatization of Public Interest: Theorizing NGO Discourse in a Neoliberal Era", Review of International Political Economy, Vol. 11 No. June 2013, pp. 155-176.

Klees, S. (1998), "NGOs: Progressive force or neoliberal tool”, Current Issues in Comparative Education, Vol. 1 No. 1, pp. 49-54.

Lee, Y.-J. (2016), “What Encourages Nonprofits' Adoption of Good Governance Policies?", Nonprofit Management and Leadership, Wiley Periodicals, Inc., Vol. 27 No. 1, pp. 95-112.

LeRoux, K. and Langer, J. (2016), "What Nonprofit Executives Want and What They Get from Board Members", Nonprofit Management and Leadership, Wiley Periodicals, Inc., Vol. 27 No. 2, pp. 147-164.

Lewis, D. (2014), Non-Governmental Organizations, Management and Development, 2nd ed., Routledge, Abingdon.

Lewis, D. (2019), "NGOs and Management Studies”, in Davies, T. (Ed.), Routledge Handbook of NGOs and International Relations, Routledge, pp. 165-178.

Li, H. (2019) "Leadership Succession and the Performance of Nonprofit Organizations: A Fuzzy-Set Qualitative Comparative Analysis. Nonprofit Management and Leadership. 2019; Vol. 29 No. 3, pp. 341-361.

Liket, K.C. and Maas, K. (2015), "Nonprofit Organizational Effectiveness: Analysis of Best Practices", Nonprofit and Voluntary Sector Quarterly, Vol. 44 No. 2, pp. 268-296.

Maier, F., Meyer, M. and Steinbereithner, M. (2016), "Nonprofit Organizations Becoming Business-Like: A Systematic Review", Nonprofit and Voluntary Sector Quarterly, Vol. 45 No. 1, pp. 64-86. 
Matus, T., Funk, R., Rios, R. and Haz, A.M. (2012), Desarrollo de Un Modelo de Gestión de Calidad Para Programas Sociales, edited by Matus, T., Vol. 1-4, Centro de Estudios de Emprendimientos Solidarios, Pontificia Universidad Católica de Chile, Santiago of Chile.

Monks, R. and Minow, N. (2011), Corporate Governance, 5th ed., John Wiley \& Sons, Sussex.

Moore, M. and Stewart, S. (1998), “Corporate governance for NGOs?”, Development in Practice, Vol. 8 No. 3, pp. 335-342.

Morck, R. and Steier, L. (2005), “The Global History of Corporate Governance: An Introduction", in Morck, R. (Ed.), A History of Corporate Governance around the World: Family Business Groups to Professional Managers, University of Chicago Press, Chicago, pp. 1-64.

Moya, E., Ortiz, P., Soto, V., Murden, A. and Anton, V. (2012), Transparencia y Rendicion de Cuentas Dn Organizaciones Sin Fines de Lucro [Transparency and Accountability of Nonprofit Organizations], Chile Transparente, Santiago of Chile.

Natsios, A.S. (1995), “Third World Quarterly NGOs and the UN system in complex humanitarian emergencies: Conflict or cooperation?", Third World Quarterly, Vol. 16 No. 3, pp. 405-420.

OECD. (2015a), Government at a Glance 2015, OECD Publishing, Paris, available at: http://www.oecd-

ilibrary.org/docserver/download/4215081e.pdf?expires=1490725208\&id=id\&accn ame $=$ guest\&checksum $=7$ DCF855631E423323FB9D8294543D1FD $($ accessed 28 March 2017).

OECD. (2015b), G20/OECD Principles of Corporate Governance, OECD Publishing, Paris, available at:https://doi.org/ttp://dx.doi.org/10.1787/9789264236882-en.

Ostrower, F. (2014), Boards as an Accountability Mechanism, Washington, DC, available at: https://www.urban.org/sites/default/files/publication/22636/413146Boards-as-an-Accountability-Mechanism.PDF (accessed 21 November 2017).

Renz, D. (2016), “Leadership, Governance, and the work of the Board”, in Renz, D. and Herman, R. (Eds.), The Jossey-Bass Handbook of Nonprofit Leadership and Management, 4th ed., Jossey-Bass, pp. 127-166.

Rios, R. (2006), “Certificación de intervenciones sociales”, Revista de Trabajo Social, Vol. 73 No. 1, pp. 131-140.

Roberts, J. (2005), “Agency Theory, Ethics and Corporate Governance”, Advances in Public Interest Accounting, Vol. 11, pp. 249-269. 
Rodríguez, C.G. (1995), “La encrucijada de las ONG en Chile”, Estudios Sociológicos, Vol. 13 No. 37, pp. 163-180.

Ronalds, P. (2010), The Change Imperative: Creating the next Generation NGO, Kumarian Press, Sterling, VA.

Salipante, P. (2014), "Lessons for Governance Research and Practice", in Cornforth, C. and Brown, W.A. (Eds.), Nonprofit Governance: Innovative Perspectives and Approaches, Routledge, London, pp. 272-288.

Salvato, C. and Rerup, C. (2011), "Beyond Collective Entities : Multilevel Research on Organizational Routines and Capabilities", Journal of Management, Vol. 37 No. 2, pp. $468-490$.

Sandberg, B. (2016), "Against the Cult(ure) of the Entrepreneur for the Nonprofit Sector", Administrative Theory \& Praxis, Vol. 38 No. 1, pp. 52-67.

Sanzo-Pérez, M.J., Rey-Garcia, M. and Álvarez-González, I. (2017), "The Drivers of Voluntary Transparency in Nonprofits: Professionalization and Partnerships with Firms as Determinants", VOLUNTAS: International Journal of Voluntary and Nonprofit Organizations, Vol. 28, available at:https://doi.org/10.1007/s11266-0179882-9.

Soto, F. and Viveros, F. (2017), "Las organizaciones de la Sociedad Civil desde su marco jurídico e institucional: Configurando un actor social [Civil society organizations from their legal and institutional framework: Setting up a social actor]", in Irarrázaval, I. and Streeter, P. (Eds.), Sociedad En Acción:

Construyendo Chile Desde Las Organizaciones de La Sociedad Civil, 1st ed., Centro UC Políticas Públicas \& Chile + Hoy, Santiago of Chile, pp. 94-120.

Strobel, M., Tumasjan, A., Spörrle, M. and Welpe, I.M. (2017), “Fostering employees' proactive strategic engagement: Individual and contextual antecedents", Human Resource Management Journal, Vol. 27 No. 1, pp. 113-132.

The Guardian. (2018), "Haiti shuts down Oxfam GB over prostitution scandal”, The Guardian, 14 June, available at:

https://www.theguardian.com/world/2018/jun/14/haiti-shuts-down-oxfam-gb-overprostitution-scandal.

United Nations Statistics Division. (2003), Handbook on Non-Profit Institutions in the System of National Accounts, United Nations, New York, available at: https://unstats.un.org/unsd/publication/seriesf/seriesf_91e.pdf (accessed 3 January 2018).

Valentinov, V. (2011), “Accountability and the public interest in the nonprofit sector: a 
conceptual framework", Financial Accountability \& Management, Vol. 27 No. 1, pp. $32-42$.

Vromen, J.J. (2011), "Routines as multilevel mechanisms", Journal of Institutional Economics, Vol. 7 No. 2, pp. 175-196.

Weisbord, M. (1976), “Organizational Diagnosis: Six Places To Look for Trouble with or Without a Theory”, Group \& Organization Studies, Vol. 1 No. 4, pp. 430-447.

Wyatt, M. (2004), A Handbook of NGO Governance, European Center for Not-forProfit Law, Budapest, available at:

http://providus.lv/article_files/1420/original/ngo_govern.pdf?1331192192 (accessed 15 November 2017).

Zattoni, A. and Cuomo, F. (2008), "Why Adopt Codes of Good Governance? A Comparison of Institutional and Efficiency Perspectives", Corporate Governance: An International Review, Vol. 16 No. 1, pp. 1-15. 